\section{Mislykket gjenbruk}

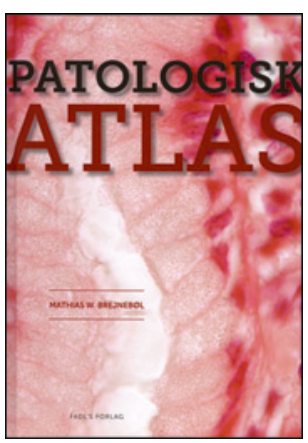

Mathias Willadsen Brejnebøl

Patologisk atlas

138 s, ill. København: FADL's Forlag, 2014

Pris DKK 250

ISBN 978-87-7749-713-1

Undertegnede har tidligere hatt glede av patologibøkene Almen patologi (2. utgave 2005) og Klinisk patologi (1. utgave 2004) fra FADL's forlag i undervisningen av bioingeniører. Stor er derfor skuffelsen over det i sannhet «patologiske» atlaset fra 2014.

Ideen bak atlaset er god, nemlig å sammenholde patologiske tilstander i vev mot normal histologi i samme organ, med en enkel tekst som legger vekt på mønstre for å gjenkjenne noen grunnleggende tilstander i den generelle patologien (adaptasjon, celledød, betennelse, sårtilheling, sykdommer i kar og malignitet). Dessverre er forsøket mislykket.

Forlaget har ukritisk gjenbrukt illustrasjoner fra tidligere utgivelser, som Patologi, Almen patologi, Klinisk patologi og Histologi. En rekke av illustrasjonene har ikke tålt oppblåsing til et større format. Flere var opprinnelig uskarpe, men er likevel tatt med og blåst opp, noen har fått kuttet det vesentligste området under oppblåsingen, og flere er av snitt med så dårlig kvalitet på fremføring og farging at det er påfallende at de i det hele tatt er kommet på trykk. Fargemetoder er bare unntaksvis nevnt, men det brukes sannsynligvis flere. Og da på en slik måte at hele vitsen med sammenlikningen mellom normalt og patologisk vev forsvinner, med ulike farger på patologisk og normalt vev, uten system og som regel uten forklaring. Utvalgene av normalt vev gir stedvis ingen mening, som i de gjentatte bildene av normal hjertemuskulatur eller i illustrasjonen av purulent betennelse, der et lite utsnitt av lunge skal illustrere det normale motstykket til et uskarpt bilde av puss, utelukkende bestående av granulocytter (tror jeg, bildet er for uskarpt).

Som et omen møter man i teksten, i det første eksemplet, en forveksling der normalt vev omtales som patologisk, og omvendt. Og når brystkjertelvev - riktignok knapt gjenkjennelig i en blass, gulaktig udefinerbar fargegjengivelse - betegnes som «normalt lungevæv med en normal udførselsgang», får man som anmelder problemer med å finne passende ord. Som atlas er dette ikke verdt papiret det er trykt på, uansett hvilken målgruppe utgivelsen er beregnet på.

\section{G. Cecilie Alfsen}

Overlege, Avdeling for patolog

Akershus universitetssykehus

\section{Ikke lett å lese - ikke lett å huske}

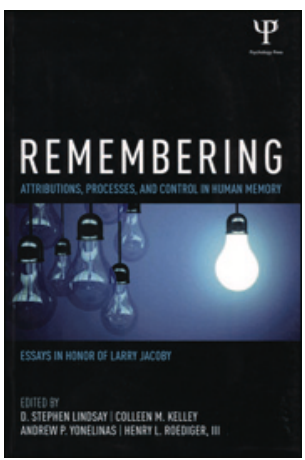
Andrew P. Yonelinas et al, red. Remembering ISBN 978-1-84872-554-6

D. Stephen Lindsay, Colleen M. Kelley,

Attributions, processes, and control in human memory. 381 s, tab, ill. New York, NY: Psychology Press, 2014. Pris USD 65

Boken er et festskrift til den amerikanske psykologen Larry Jacoby, basert på et symposium arrangert til hans ære. Larry Jacoby er kjent for å fremme den oppfatning at kognisjon ikke er sammensatt av separat virkende, uavhengige delprosesser, som persepsjon, bedømmelse, hukommelse osv., men snarere bør forstås som et komplekst samspill av slike kognisjonskomponenter. Til studiet av dette samspillet har Jacoby og hans elever og kolleger utviklet en spesiell metodisk tilnærming kalt «prosessdissosiering». Med denne metoden er særlig samspillet mellom viljestyrte kontrollprosesser og mer automatiske kognisjonsprosesser blitt undersøkt.

På et forskningsmøte mellom kolleger engasjert i felles problemstillinger og felles metodebruk vil naturligvis mye av kommunikasjonen møtedeltakerne seg i mellom ta mange forutsetninger for gitt og kjent. De fleste innleggene er for den mer allment orienterte leseren, selv med generell kunnskap om samtidens kognisjonspsykologi, altfor «tekniske» til at den fremlagte forskningens mer grunnleggende betydning når frem til leseren. Den som ønsker å danne seg et inntrykk av hvordan moderne kognisjonsforskning studerer hukommelse, vil imidlertid få en god orientering.

Blant de 22 kapitlene finnes dog noen som med brukbart utbytte kan leses uten kjennskap til forskningstradisjonens tekniske detaljer, for eksempel om hukommelsens pålitelighet, feilattribusjon av hukommelseskilder og trenbarhet av strategier for glemselskompensasjon.

Som nevnt er et gjennomgangstema samspillet mellom automatiske og kontrollerte kognisjonsprosesser. Når vi eksempelvis husker en bestemt informasjon, vil gjerne noen «minnespor» melde seg av seg selv. Andre vil man gjerne måtte søke mer eller mindre systematisk etter. Kognisjonskomponenter utenfor egenkontroll vil stadig påvirke igangværende mental aktivitet som ofte kan være ulike sorter oppgavemestring. For eldre gjelder typisk tiltakende svekket hemming av irrelevante automatiske prosessers virke. Her berøres et område hvor mer kunnskap forhåpentlig kan ventes omsatt i praktisk nyttige hjelpetiltak.

Det ligger i et festskrifts form en tone av hyllest. Festskrifter er derfor sjelden kilden til den mest kritiske diskusjonen av en forskers eller forskningsgrens bidrag. Fortjenstfullt belyser man i mange kapitler den nære sammenhengen som råder mellom oppmerksomhet og hukommelse. Svekket konsentrert oppmerksomhet, under innlæring og informasjonsregistrering, er minnets viktigste utfordrer. For andre enn eksperten er boken ikke lett å lese, og dermed vanskelig å huske.

Med sin fokuserte vinkling er målgruppen nok mer forskeren enn den allment nysgjerrige leseren.

Tore Helstrup

Professor emeritus, Psykologisk institutt

Universitetet i Oslo 